\title{
Primary Hepatic Actinomycosis
}

\section{Primer Hepatik Aktinomiköz}

\author{
Cem Emir Güldoğan, Salih Burak Gündoğdu, Erdinç Çetinkaya, Şiyar Ersöz, \\ Hüseyin Berkem, Mesut Tez
}

Ankara Numune Eğitim ve Araştırma Hastanesi, Genel Cerrahi Kliniği

Dergiye Ulaşma Tarihi:12.11.2015 Dergiye Kabul Tarihi:10.12.2015 Doi10.5505/aot.2016.43531

\section{ÖZET}

Aktinomikoz nadir görülen kronik enfeksiyöz bir hastalıktır. En sık görülen formu servikofasiyal enfeksiyondur. Karaciğer tutulumu tüm aktinomikoz enfeksiyonlarının \%5'ini oluşturur . Abdominal aktinomikoz enfeksiyonu bulunan olguların yaklaşık \%15'inde karaciğer lezyonları eşlik etmekte ve karaciğer tutulumunun, batın içindeki başka bir enfeksiyon odağına, sekonder olarak meydana geldiğine inanılmaktadır. Ancak bazı olgularda enfeksiyonun kaynaklandığı primer odak saptanamaz ve bu olgular primer ya da izole hepatik aktinomikoz olarak sınıflandırılır. Genellikle tek bir apse odağı şeklinde, hassas, sert, fikse görünümdedir. Bazen tümör ile karıştırılabilir. Mikroskopik tanısı, gram(+) basil şeklindeki mikroorganizmaların görülmesi veya kültürde üretilmesi ile konulur.

Anahtar kelimeler: karaciğer, aktinomikozis, inflamatuar psödotümör

\begin{abstract}
Actinomycosis is a rare chronic infectious disease. The most common form is cervicofacial infection. Hepatic involvement constitutes 5\% of all actinomycosis infections. Approximately 15\% of patients with abdominal actinomycosis is accompanied by liver lesions. Liver involvement is believed to occur as a secondary to another infected focus in the abdomen. However, in some cases, the infection's primer focus can not be detected and are classified as primary or isolated hepatic actinomycosis.

Generally they are in the form of a single, sensitive, firm, and fixed abscess. Sometimes it may be mistaken as tumor. Tissue specimens for microscopic examination are necessary for diagnosis.

Key words: liver, actinomycosis, inflammatory pseudotumor
\end{abstract}

\section{Olgu Sunumu}

51 yaşındaki erkek hasta, karın ağrısı ve sağ üst kadranda şişlik şikayeti ile acil servise başvurdu. Çiftçilikle uğraşan hastanın bilinen ek hastalığ1 yoktu ve 6 y1l önce laparoskopik kolesistektomi operasyonu geçirdiğini ve karın bölgesine travma olmadığını belirtiyordu.

Fizik muaynesinde, batın sağ üst kadranda, hassasiyet ve şişlik mevcuttu.

Ultrasonografide, sağ alt kostalar düzeyinde, cilt altında yerleşim gösteren, yoğun içerikli, geniş koleksiyon alanı izlenmekteydi. Batın tomografisinde, sağ alt kostalar düzeyinde, cilt altında yerleşim gösteren, interkostal kaslara uzanan periferal kontrastlanmasi bulunan, perihepatik alana uzanan, en geniş yerinde $7 \times 3 \mathrm{~cm}$ ölçülen, loküle apse ile uyumlu, koleksiyon izlenmekteydi (Resim 1A-1B, İşaretli Ok). Hastanın laboratuar değerlerinden; beyaz küresi, karaciğer fonksiyon testleri, CRP ve sedimentasyon normaldi. Hastaya profilaktik, penicilin G, 24 milyon ü/gün tedavisi başlandı, ardından perkütan drenaj uygulandı. Kültür sonucunda actinomyces üredi. 


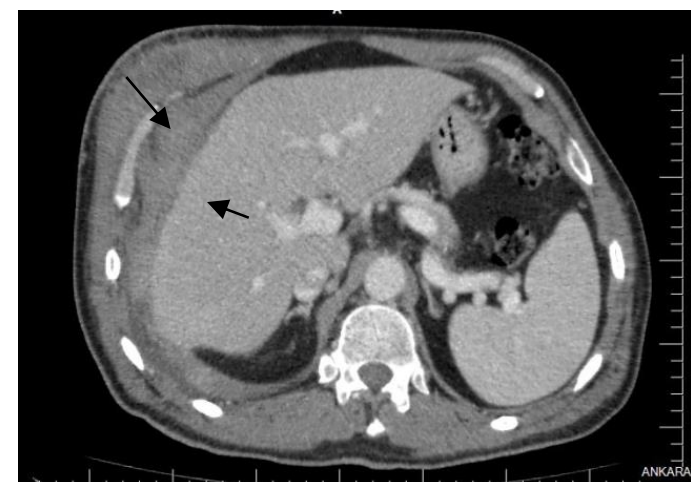

Resim 1A

\section{Tartışma}

Aktinomikoz nadir görülen kronik enfeksiyöz bir hastalıktır. En sik görülen formu servikofasiyal enfeksiyondur. Karaciğer tutulumu tüm aktinomikoz enfeksiyonlarının $\% 5$ 'ini ancak oluşturmaktadır $(1,2)$, kronik süpüratif ve granülamatöz bir hastalıktır. Gram pozitif anaerop bir bakteri olan ve siklıkla orofarinks florasinda bulunan, Actinomyces israelii en s1k rastlanan etken mikroorganizmadır $(5,6)$.

Aktinomiköz kesin tanısı için tipik olan "sülfür granüllerinin" mikroskopik olarak gösterilmesi ya da anaerop kültürde "Actinomyces" mikroorganizmalarının üretilmesi gereklidir. Abdominal aktinomikoz ciddi ve progresif bir peritoneal enfeksiyondur. En sik ileoçekal bölgede yerleşir. $\mathrm{Bu}$ olgularda predispozan etken olarak, çoğunlukla uzun süreli RİA kullanımı bildirilmektedir (5-7). Bilinen diğer risk faktörleri arasında intestinal perforasyon ve geçirilmiş cerrahi operasyonlar ile apandisit ya da divertikülit gibi intraabdominal enfeksiyonlar bulunmaktadır.

Karaciğer tutulumunun çoğunlukla intraabdominal başka bir odaktan, doğrudan yayılım sonucunda, veya portal ven aracılığ ile olduğu düşünülmektedir. Nonspesifik radyolojik bulguları nedeniyle aktinomikotik karaciğer apsesi genellikle tanınamaz. Enfeksiyon kaynağı veya primer odağı saptanamayan olgular, primer hepatik aktinomiköz olarak adlandırılır (3). Olgumuz yapılan incelemeler sonucunda, başka bir enfeksiyon odağı bulunmaması nedeniyle,

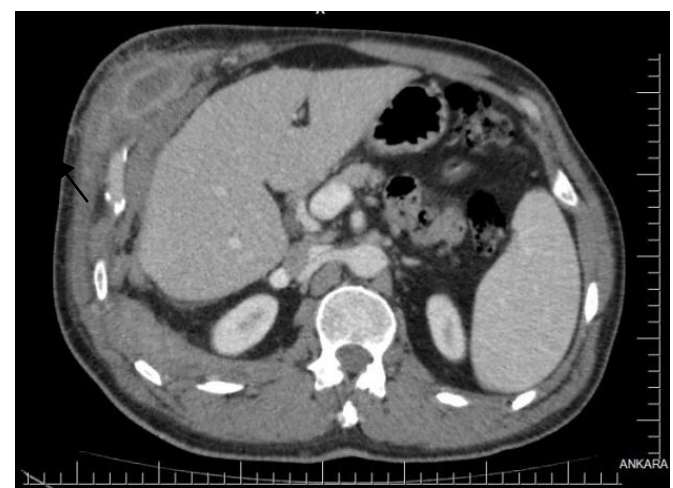

Resim 1B

primer hepatik aktinomiköz olarak değerlendirilmiştir.

Geçmişte kesin tanısı için, sıklıkla açık cerrahi eksplorasyon ve tedavi amaci ile cerrahi drenaj yapılmaktayd. Radyolojik inceleme yöntemleri ve perkütan iğne aspirasyon tekniklerinin gelişmesiyle birlikte, tanı ve tedavi amacıyla açık cerrahi eksplorasyon gerekliliği azalmıştır (4).

Çıkar çatışması: Yazarların bu çalışmada hiçbir ürün ve firmayla çıkar ilişkisi bulunmamaktadır.

\section{Kaynaklar}

1. Ubeda B, Vilana R, Bianchi L, Pujol T. Primary hepatic actinomycosis: associationwith portal vein thrombosis. AJR Am JRoentgenol 1995; 164:231-232

2. Shah HR, Williamson MR, Boyd CM, BalachandranS, Angtuaco TL, McConnellJR. CT findings in abdominal actinomycosis.J Comput Assist Tomogr 1987; 11:466-469

3. Cheng YF, Hung CF, Liu YH, Ng KK,Tsai CC. Hepatic actinomycosis with portal vein occlusion. Gastrointest Radiol 1989; 14:268-270

4. Miyamoto MI, Fang FC. Pyogenic liver abscess involving Actinomyces: case report and review. Clin Infect Dis 1993;16:303-309

5. Laurent TH, Grandi P, Schnyder P. Abdominal actinomycosis associated with intrauterine device: $\mathrm{CT}$ features. Eur Radiol 1996; 6:670-673

6. Williams CE, Lamb GHR. Pelvic actinomycosis: beware the intrauterine contraceptive device. $\mathrm{Br} \mathrm{J}$ Radiol 1990; 63:134

7. Chan YL, Cheng CSK. Mesenteric actinomycosis. Abdom Imaging 1993; 18: 286 